\title{
HISTORY OF THE BUILDING OF THE ARCHAEOLOGICAL MUSEUM IN KRAKÓW AT THE EXHIBITION "THE HISTORY OF THE BUILDING HOUSING THE ARCHAEOLOGICAL MUSEUM IN KRAKÓW"
}

\author{
Anna TYNIEC \\ Archaeological Museum in Kraków; ul. 3 Senacka, 31-002 Krakow, Poland; \\ e-mail: tyniec@ma.krakow.pl
}

\begin{abstract}
The site currently occupied by the Archaeological Museum in Kraków abounds with finds dating back to the early medieval period. It is located on the edge of the alluvial cone of the Praqdnik, a tributary to the Vistula River. In the $9^{\text {th }}-13^{\text {th }}$ century, the area was contained within the fortified suburbium where a dwelling, productive and commercial settlement developed. After 1612, the land was donated to the Discalced Carmelite Order, and the monastery with the church of St. Michael and St. Joseph were built. In the year 1797, on the strength of the decree issued by the Austrian Emperor Joseph II (from 1782), concerning the dissolution of monastic orders, the Carmelite Order was dissolved, and the church with the monastery were confiscated by the State Treasury to be used as prison and jail cells. In 1954, Kraków authorities donated the complex to serve the needs of the Archaeological Museum in Kraków. The history of the buildings became the topic of subsequent exhibitions.
\end{abstract}

Key words: museum, history, historical stratifications, exhibition

\section{INTRODUCTION}

While researching the history of the site where the Archaeological Museum in Kraków (AMK) is nowadays located, we have made use of various archaeological, historical and iconographic sources, as well as information provided by palaeogeographers or geomorphologists.

In early medieval Kraków there existed two basic fortified complexes: the stronghold Wawel and the suburbium - Okół. Other sites which might have been fortified during 
the early medieval period, situated where roads entered the town or by fords and havens, are still poorly identified, e.g. Gródek, Skałka, Zwierzyniec or Bronowice, which might be connected with safeguarding, controlling and customs functions (Fig. 1) (see: Radwański \& Tyniec 2010 and literature therein).

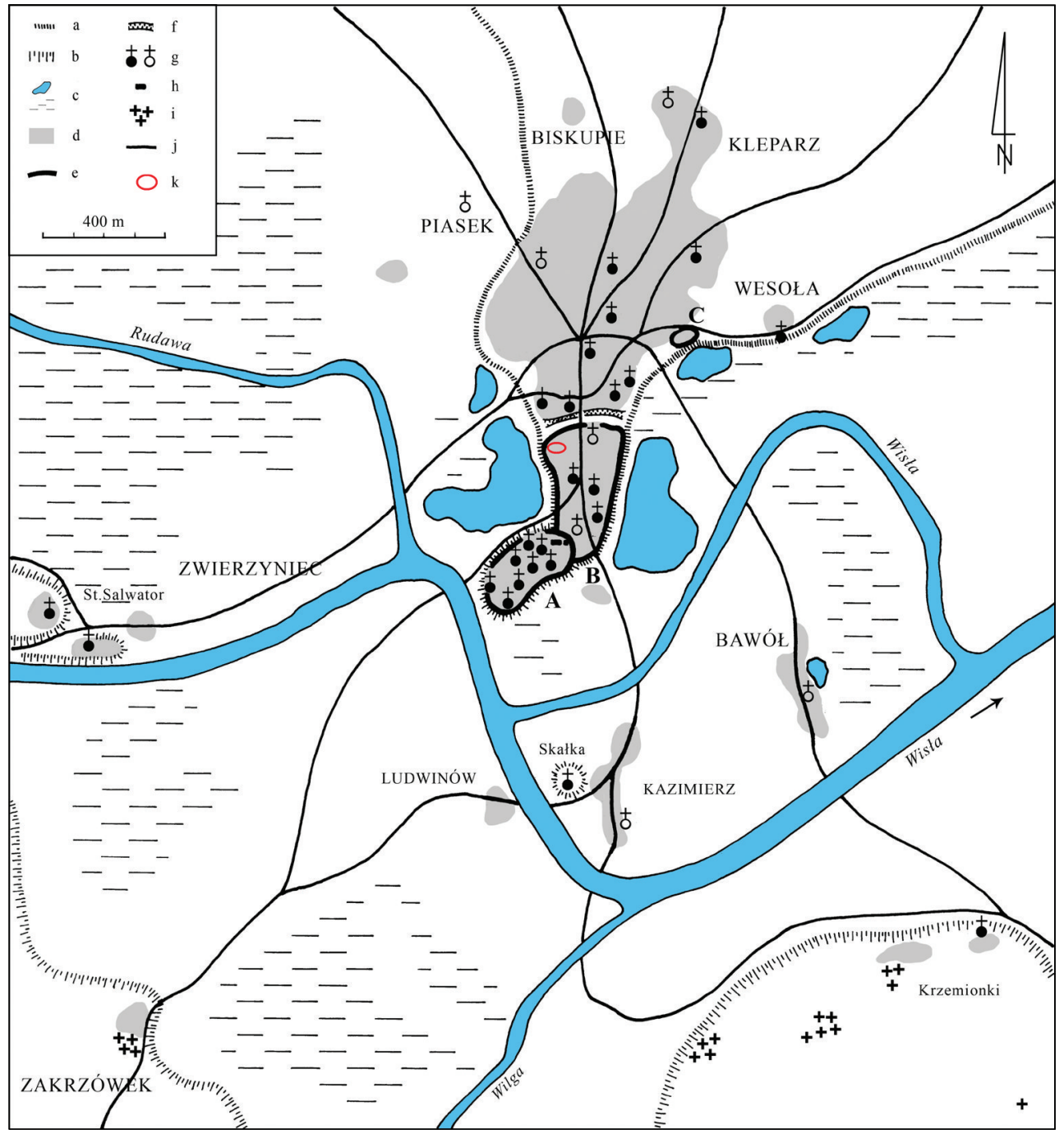

Fig. 1. Early Middle Age Kraków, VIII/IX-XIII century: A - Wawel, B - Okół, C - Gródek; a - Prądnik Cone, b - upper lands, c - boggy (rivers, ponds), d - settlement, e - fortificated places, f - Okół moat, g - churches - reliable, supposed, $\mathrm{h}$ - otherness stone buildings, i - cemeteries, j - roads, k - Archaeological Museum in Kraków (after: Radwański \& Tyniec 2010 with changes) 
Like the majority of early medieval towns, Kraków, or rather that part of it which turned into a town, developed in connection with the stronghold, Wawel, and undoubtedly constituted a centre of tribal, state and church administration in southern Poland. Besides political and social conditions, the geomorphologic landform features - terrace of the Vistula and alluvial fan of the Prądnik constituted an important element in its development. It also concerns the site where AMK is nowadays located - after all it used to be the western edge of the Okół (Tyczyńska 1968, 1974, Kmietowicz-Drathowa 1971: 41-42, 1972, Radwański 1975: 14-43).

\section{AREA OF RESEARCH}

The layout of Okół was closely linked to the land form of the middle terrace of the Vistula and the course of its edge, to which town fortifications and buildings in outskirts were adjusted. Inside, the principal direction of housing development was indicated by the main road - in the vicinity of the southern stretch of Kanonicza Street and its continuation towards the north. In the west the area had a natural borderline - the so called Żabi Kruk marshes.

Since the $9^{\text {th }}$ century, settlement in Kraków intensified. It has been registered in preserved large sections of cultural layers and archaeological objects with considerable amounts of historic materials, as well as artefacts frequently found in secondary deposits. The development of settlement can be particularly well observed in the Okół area (Radwański 1975: 35-38, 57-149 and literature therein).

Three stages of settlement have been registered in numerous archaeological excavations and boreholes in the Okól area, from the time between the beginning of the $9^{\text {th }}$ and the $2^{\text {nd }}$ half of the $10^{\text {th }}$ century (Fig. 1 ):

1. Before constructing the palisade.

2. Connected with building and functioning of the palisade.

3. A settlement after the palisade had been destroyed, which functioned until Okół was surrounded with a timber-and-earth embankment, and also with a moat in its northern part at the end of the $10^{\text {th }}$ and the beginning of the $11^{\text {th }}$ century.

\section{HISTORY OF OF THE BUILDING}

Built at the turn of the $10^{\text {th }}$ and $11^{\text {th }}$ century, the timber-stone-earth ramparts round the Okół survived until the $13^{\text {th }}$ century (Radwańska 1971: 15-40). Their relics were discovered in many places on the edge of the middle terrace, e.g. in archaeological digs carried out in the gardens of the Archaeological Museum in Kraków (Fig. 2). Houses were situated parallel to the ramparts thus creating a lane running along the wall. The course of the discovered fragments of the wall and their close connection to the lie of the land indicate defensive fortifications linking Okół and Wawel. 


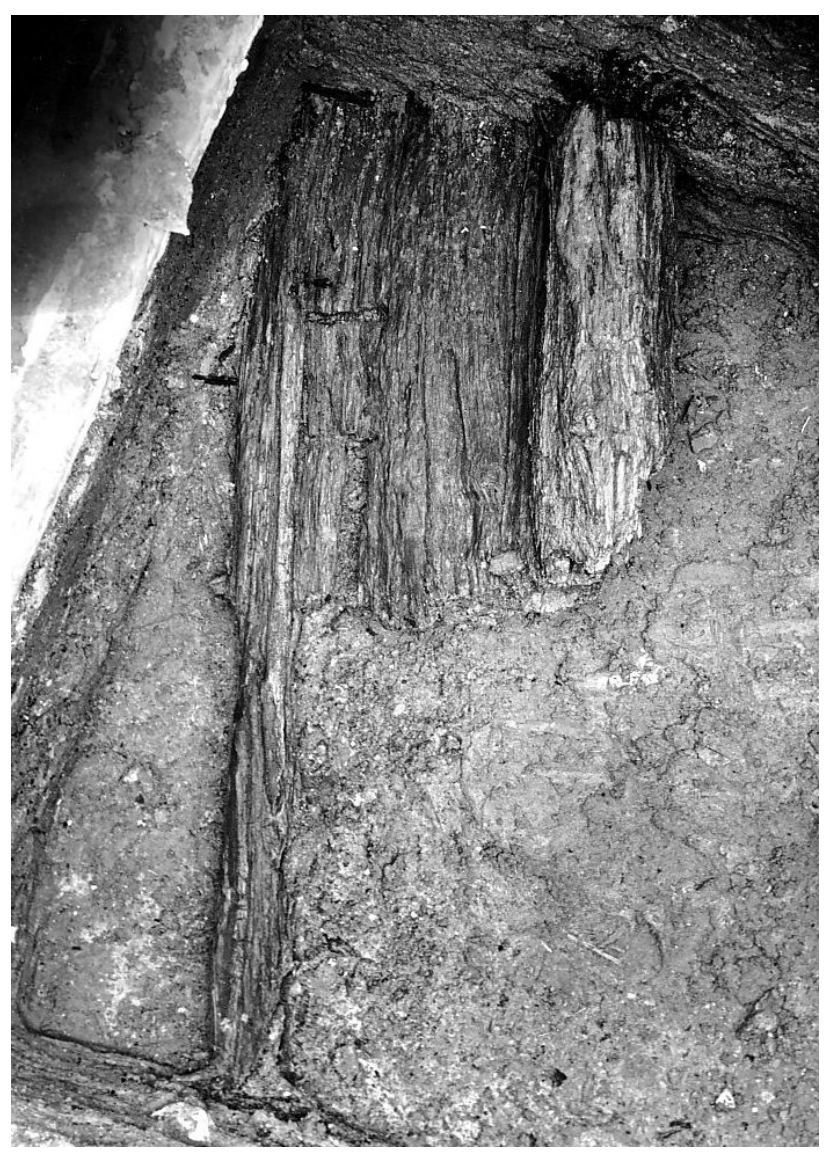

Fig. 2. Fragment of a timber-and-earth embankment. The courtyard of the Archaeological Museum in Kraków, excavation by A. Żaki 1955 (collections of OINA MAK)

During the medieval period the core of the embankment was used as a basis of a stone defensive wall for that part of the city (Radwański 1975: 121-129, 1986).

The timber-stone-and-earth fortification must have been destroyed during the Tartar invasion in the years 1259-1260 (traces of burning are visible also in excavations in the Old Market Square, e.g. by the St. Wojciech's church). Source information from 1321 mentions the fact that Wawel was linked with the chartered town by establishing "civitas nova in Okol". It might have been then that Okół was surrounded with a stone wall, or it might have taken place after 1401, when King Władysław Jagiełło allowed for digging moats between the St. Nicholas' Gate and the Grodzka Gate (see: Rajman 2004: 206-210 and literature therein). The walls have been preserved in several places of Okół in the form of negatives, or elements on the lowest floor of the city fortifications. And one such fragment of the basement of the defensive wall can be found in the premises of the AMK. Information 
concerning the buildings existing here during the medieval period is also connected with the premises of the present-day museum (Rajman 2004: 343, Wyrozumski 2007: 43). Among the known from written records and located objects are e.g.: the manor of the Tyniec abbot and the Tyniec hospice (though precise location within the built-up area is uncertain), the town bath (beneath the present-day south wing - underground sections of the city wall were used in the bath construction), noblemen's manors (assumed location) of Gniewosz from Dalewice and of the Tęczyński family - the Painted Manor in the "Kanonia" street (Strzelecka 1956, Borowiejska-Birkenmajerowa 1972, Tobiasz 1980). After 1612, when the Order of the Discalced Carmelites came into possession of the premises of the Tyniec abbot's manor and the town bath, they began to rebuild it to suit the needs of the monastery and the erect the church of St. Michael and St. Joseph (consecrated in 1635). In 1660, the city handed over the Masons' Tower to the order (its relics are visible in the bottom parts of the tower), the last lay object within the complex.

The church of St. Michael and St. Joseph was built in the early Baroque style (Langman 1934a, 1934b, 1934c, 1939, Marecki 2005: 2-3). It might have been designed by an architect working in Kraków at that time, Giovanni Trevano (in Poland from 1595) (Małkiewicz 2003: 53). According to the principles set for the newly built Carmelite churches, its shape and size corresponded to the church Santa Maria della Scala in Rome. No reliable images of the church of St. Michael and St. Joseph have been preserved. Its plan has been recreated only theoretically (on the basis of the plan of Kraków made for Kołłątaj) - the width of the facade over $20 \mathrm{~m}$, inside length $38 \mathrm{~m}$, the length of the nave $25 \mathrm{~m}$, presbytery $12 \mathrm{~m}$, the width of the transept arms, square in the cross over $15 \mathrm{~m}$, width of the presbytery over $8 \mathrm{~m}$, diameter of arches in the nave $3.5 \mathrm{~m}$ (see: Marecki 2005: 2-3). Generous donations to the Counter-Reformation order resulted in magnificent altars, sculptures, portals and gravestones from black marble from Dębniki (Langman 1939).

In 1797, on the strength of the decree issued by the Emperor of Austria, Joseph II, in 1782, concerning the dissolution of those monastic orders which did not conduct scientific or educational work, or take care of the poor, the Carmelite order by the church of St. Michel and St. Joseph in Kraków was dissolved, and the church, monastery and remaining monastic buildings were confiscated by the State Treasury to serve as a prison and jail rooms.

Monastery premises were refurbished to accommodate prison cells, and the deteriorating church was demolished in 1872 . Since 1835, the rich interior decoration of the church was gradually dismantled. After demolishing the church, a new courthouse and a chapel were erected in its place.

Monastery buildings were converted into prison cells, while the church served as a prison chapel and, after almost 100 years, the dilapidated building was finally demolished in 1872 . Since 1835 , the lavish interior decoration of the church was gradually dismantled and moved to other church objects. These items include altars (Fig. 3) made from black limestone from Dębnik, painting of St. Joseph, a crucifix, a figure of St. Michael killing 
the dragon, portal frameworks and small elements of interior decoration as well as noblemen's tombstones. They can be found in the church of St. Mark in Kraków, the Bernardine church at the foot of the Wawel Hill St. Katharine's church in Kraków's Kazimierz and church of St. Wojciech in Jaworzno. The largest set of altars, also made of wood, can be found in the Franciscan church in Kraków.

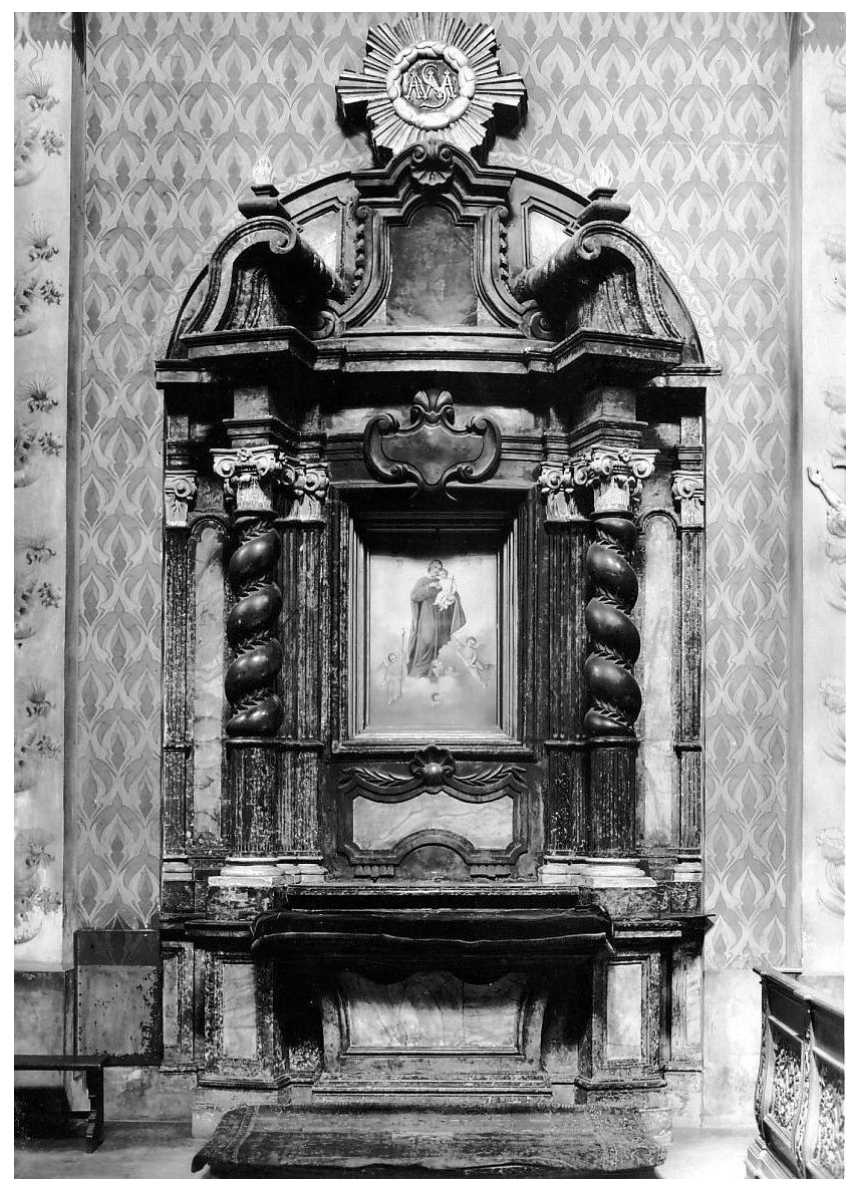

Fig. 3. The altar of the church St. Joseph and St. Michael, the state of 1930s now in the church of St. Catherine in Kraków (after: Langman 1939)

In 1954, Kraków authorities transferred the complex of former prison buildings of St. Michael's (the colloquial name of prison from 19th century, which used the name of the Carmelite church dedicated to St. Michael stuck in the communal memory) to the Archaeological Museum in Kraków (Fig. 4). In the years 1958-1966, the buildings were completely refurbished and adopted to meet the needs of a museum. 

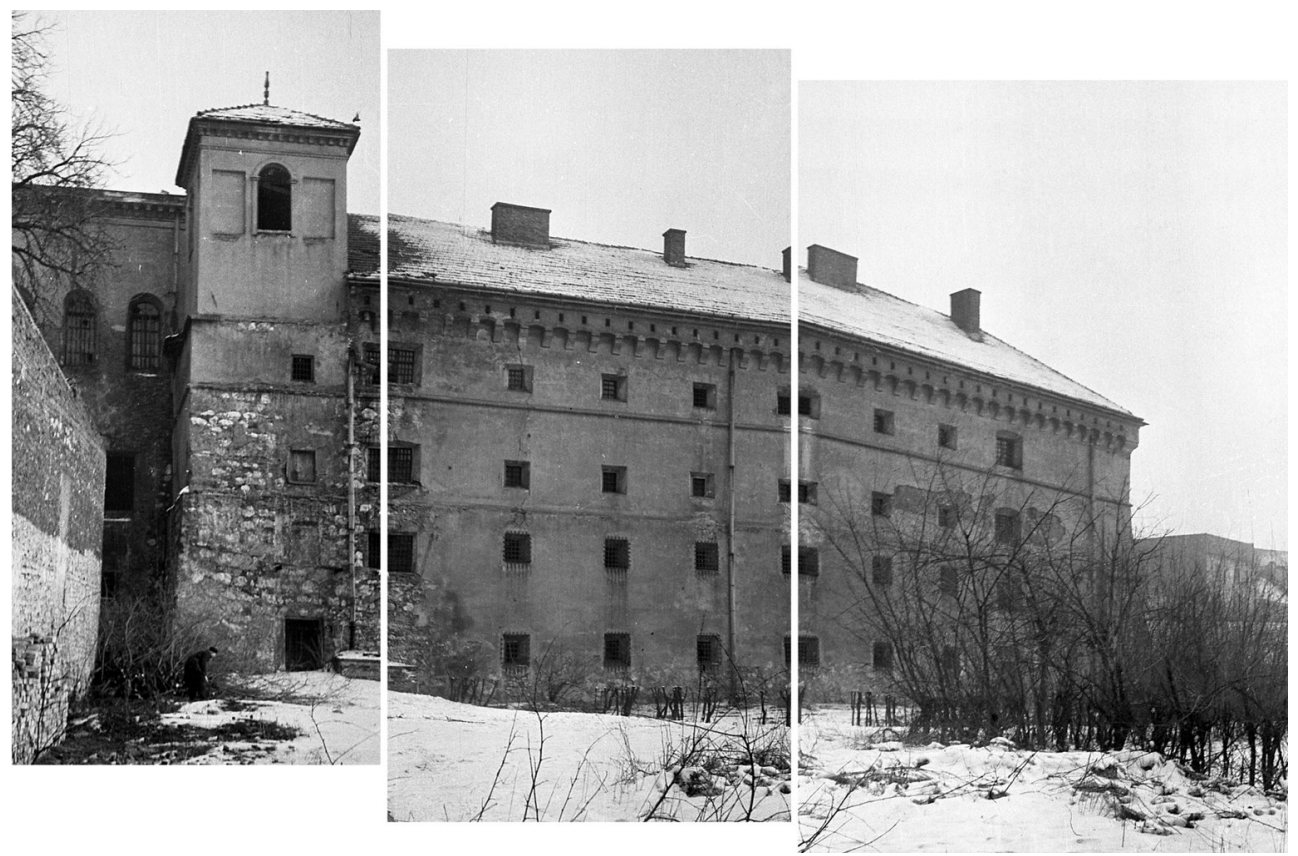

Fig. 4. The building of the Archaeological Museum in Kraków before the renovation - 1950s (collections of OINA MAK)

Since then, exhibitions presenting the history of the place have been displayed three times - narration in the two previous exhibitions concentrated in the times closest to us - on recreating the history of the prison and prisoners themselves (based on archive materials kept in the Centre of Scientific Information and Archive - OINA of the Archaeological Museum in Kraków). They had clearly defined political overtones.

The first attempt at presenting the history of the edifice was the exhibition entitled "People and walls" opened soon after the Archaeological Museum in Kraków had moved to its new seat at 3 Senacka Street (it functioned during the period from September 1967 till September 1990). It consisted of items used in prison and information boards placed in the corridor and cells of the $2^{\text {nd }}$ level of the cellars. Visitors also had access to the so called seclusion cell. The exhibition was entirely subordinated to the expectations of the authorities at the times - it showed primarily facts and exhibits associated with political prisoners from the 1930s. Similarly located and constructed was the next exhibition, opened in September 1992, entitled "St. Michael. Monastery. Prison. Museum." It also reflected the history of the building solely by means of texts and few illustrations mounted on boards. The history of the premises constituted merely a background for information concerning political prisoners. The exhibition was accessible only to organised groups of visitors and ceased to function after approximately five years (it is difficult to pinpoint a concrete date of closing the exhibition, since its rooms were gradually converted into storage space). 
The creators (Anna Tyniec is the author of the exhibition scenario), representing the Institute of National Remembrance, Kraków Branch, have been invited to collaborate on the current exhibition, which intended to present the rich history of the place. The institute's employees Joanna Dutka and Maciej Zakrzewski prepared the part of the exhibition concerning the history of St. Michael's prison during the period of Nazi occupation and the first years after World War II (Tyniec et al. 2009). The motto of their work was written by Tadeusz Reyman (1899-1955), one of the former directors of the Archaeological Museum in Kraków (Reyman 1937: 47): "An Archaeological Museum is a very distinct notion, serving an entirely different purpose than other museums [...] What should it really be? Primarily, it ought to be a refuge, a shelter for preserved and discovered historic objects."

Reyman's long-lasting endeavours to acquire suitable exhibition space to house archaeological collections and displays of the Archaeological Museum (Reyman 1947, Legacy of Tadeusz Reyman, see also: Woźny in print) resulted, in 1954, in donating the premises in Senacka and Poselska streets to serve this purpose. Acquiring this location also led to the challenge that archaeologists were faced with, i.e. exhibiting a monument whose merely tiny part was of archaeological significance which, in that context, the museum was building itself.

The most vital issue, however, was the manner of presenting architectonic relics and selected rooms, existing within the planned exhibition space, which were to become integral elements of the display and de facto exhibits presented in it (see: Świecimski 1996a: 33, 41, 46, 1996b: 13-15, 2004).

\section{SUMMARY}

The fundamental task was to use the preserved architectonic elements as museum exhibits (Figs 5, 6), which were to fulfil not only the function of an "architecture zone", but also exist as an "exhibit zone" as defined by Jerzy Świecimski (1992: 64 and next). In this case the zones interpenetrated and existed in a complete interrelation. Additionally, the demand for exhibit authenticity was absolutely fulfilled. Being located within the planned exhibition space and constituting an integral part of its factual content, they required the display composition to be adjusted to them. One could quote here yet another statement by the already mentioned author: "Defining a museum object as a thing can be treated solely as a "technical" definition. It does not reflect the significant structure of a cultural item, nor does it consider the fact that not all features of a museum object can be narrowed down to features of a thing” (Świecimski 1992: 73). Theoretically, he related them mainly to „works of art", but in a concrete case they allow for revealing the whole factual and emotional content associated with the exhibition space. The structure of that part of the building where the exhibition is presented allowed for selecting and highlighting architectonic elements and rooms not as background or setting, but as objects of the utmost importance. Those elements are: relics of a medieval stone city wall, a death wall and a death cell. Their unique role has resulted from the meaning they convey. 


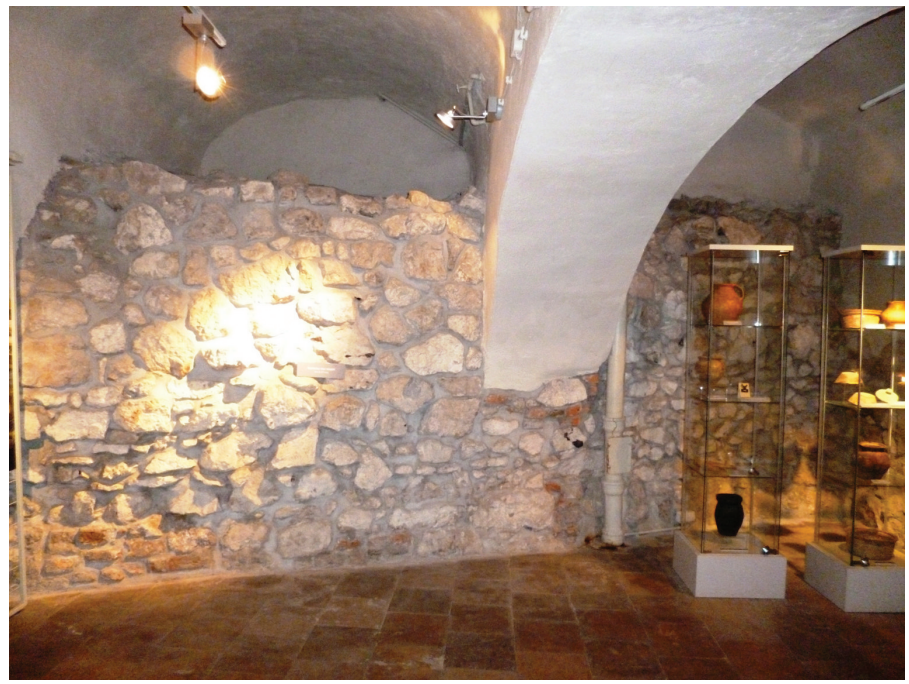

Fig. 5. Part of the exhibition "The history of the building housing the Archaeological Museum in Kraków” - fragment of XIV-century city stone wall (A. Tyniec)

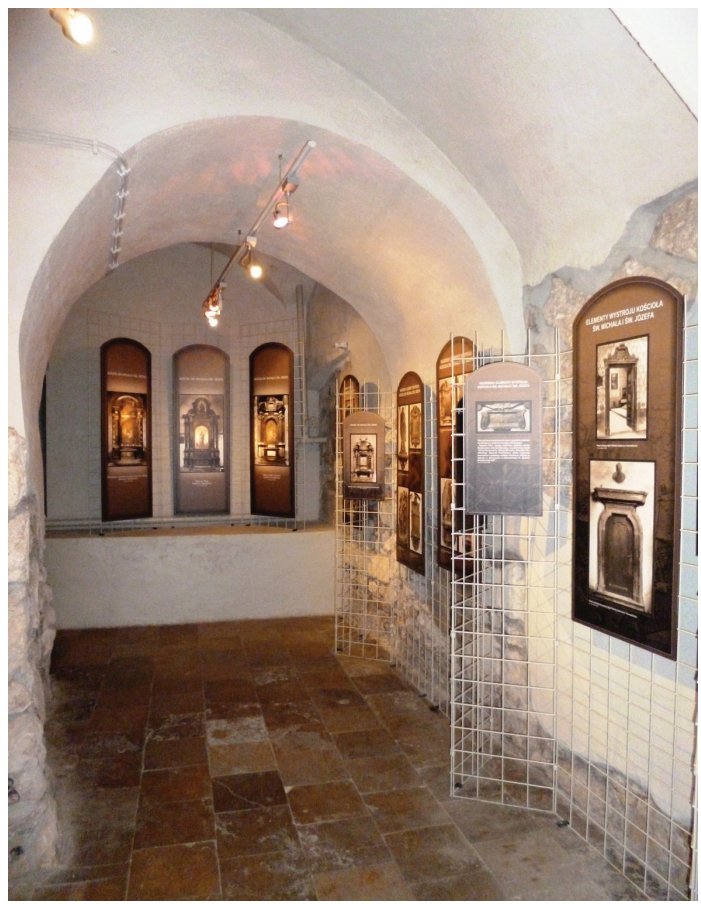

Fig. 6. Part of the exhibition "The history of the building housing the Archaeological Museum in Kraków" (A. Tyniec) 


\section{REFERENCES}

Borowiejska-Birkenmajerowa M., 1972. Relikty średniowiecznej architektury obronnej w obrębie zespołu św. Michała w Krakowie na tle dawnego układu urbanistycznego. Teka Komisji Urbanistyki i Architektury, 6, 181-193.

Kmietowicz-Drathowa J., 1971. Geologiczne podstawy odtwarzania pierwotnej topografii Krakowa w świetle geologii. Materiały Archeologiczne, 12, 41-52.

Kmietowicz-Drathowa J., 1972. Przegląd dotychczasowych rekonstrukcji topografii Krakowa w świetle geologii. Materiały Archeologiczne, 13, 41-56.

Langman J., 1934a. Dawne klasztory oo. Karmelitów bosych w Polsce. Wnętrze zburzonego kościoła karmelickiego śś. Michała i Józefa w Krakowie. Głos Karmelu, VIII, 4, $154-157$.

Langman J., 1934b. Dawne klasztory oo. Karmelitów bosych w Polsce. Wnętrze zburzonego kościoła karmelickiego śś. Michała i Józefa w Krakowie. Głos Karmelu, VIII, 5, 198-202.

Langman J., 1934c. Zabytki pozostałe po zburzonym kościele śś. Michała i Józefa w Krakowie. Głos Karmelu, VIII, 6, 233-235.

Langman J., 1939. Nieistniejacy kościót świętych Michała i Józefa niegdyś Karmelitów Bosych $w$ Krakowie [manuscript, unpubl.].

Małkiewicz A., 2003. Rzym a barokowa architektura Krakowa. Rocznik Krakowski, 69, 4775.

Marecki J. OFMCap, 2005. Wpływ sztuki karmelitańskiej na kształtowanie życia religijnego w Polsce. [in:]: Ruszała A. OCD (ed.), Cztery wieki Karmelitów Bosych w Polsce 1605-2005, Wydawnictwo Karmelitów Bosych, Kraków, 1-10.

Radwańska T., 1971. Umocnienia Okołu w Krakowie. Materiały Archeologiczne, 12, 1540.

Radwański K., 1975. Kraków przedlokacyjny. Rozwój przestrzenny. Kraków.

Radwański K., 1986. Mury obronne Krakowa i Kazimierza w badaniach archeologicznych. Materiaty Archeologiczne, 23, 65-73.

Radwański K. \& Tyniec A., 2010. Cracow in archaeological reserch. [in:]: Buko A. \& McCarthy M. (Eds), Making a Medieval Town. Patterns of Early Medieval Urbanization, Institute of Archaeology Polish Academy of Sciences, Institute of Archaeology University of Warsaw, Warszawa, 179-190.

Rajman J., 2004. Kraków: zespół osadniczy, proces lokacji, mieszczanie do 1333. Wydawnictwo Naukowe Akademii Pedagogicznej, Kraków.

Reyman T., 1937. Rola muzeum archeologicznego. Orli Lot, 18, 47-51.

Reyman T., 1947. Sami nie wiecie co posiadacie. Na marginesie badań archeologicznych pod Krakowem. Tygodnik Powszechny, III/36/129, 8.

Rydzewski J., 2010. Muzeum Archeologiczne w Krakowie w latach 1955-2005. Materiały Archeologiczne, 38, 219-231. 
Strzelecka A., 1956. Z przeszłości powięziennych budynków św. Michała w Krakowie. Biuletyn Historii Sztuki, 18/2, 281-286.

Świecimski J., 1992. Wystawy muzealne. T. 1: Studium z estetyki wystaw. Kraków. Wydaw. Jan Kajetan Młynarski, Kraków.

Świecimski J., 1996a. Muzea i wystawy muzealne. T. 3. Wydawnictwo Naukowe DWN Polska Akademia Nauk - Oddział w Krakowie, Kraków.

Świecimski J., 1996b. Muzea i wystawy muzealne. T. 4. Wydawnictwo Naukowe DWN Polska Akademia Nauk - Oddział w Krakowie, Kraków.

Świecimski J., 2004. Eksponat muzealny w aspekcie zagadnień ontologicznych, estetycznych i etycznych. Zeszyty Naukowe Uniwersytetu Jagiellońskiego, MCCLXVIII, Opuscula Musealia, 13, 9-21.

Tobiasz M., 1980. Historyczny rozwój architektury poklasztornego zespołu więziennego św. Michała w Krakowie do roku 1955. Teka Komisji Urbanistyki i Architektury, 14, $13-24$.

Tyczyńska M., 1968. Rzeźba terytorium miasta Krakowa. Folia Geographica. Series Geographica-Physica, 8, 19-43.

Tyczyńska M., 1974. Rzeźba i budowa geologiczna terytorium Miasta Krakowa. Folia Geographica. Series Geographica-Physica, 1, 9-31.

Tyniec A., Dutka J. \& Zakrzewski M., 2009. Dzieje najstarsze i stare gmachu Muzeum Archeologicznego $w$ Krakowie [folder of the exhibition of Archaeological Museum in Kraków]. Kraków.

Woźny M. [in print]. W nowej rzeczywistości... Poszukiwanie siedziby dla Krakowskiego Muzeum Archeologicznego. Rocznik Krakowski.

Wyrozumski J., 2007. Lokacja 1257 na tle rozwoju Krakowskiego zespołu osadniczego. [in:] Lichończak-Nurek G. (red.), Kraków europejskie miasto prawa magdeburskiego 1257-1791: katalog wystawy, Muzeum Historyczne Miasta Krakowa, Kraków, 34-48. 